\title{
Vers libre in theory and practice
}

\section{Willem van Doorn}

To cite this article: Willem van Doorn (1921) Vers libre in theory and practice, English Studies, 3:1-6, 1-7, DOI: 10.1080/00138382108596411

To link to this article: http://dx.doi.org/10.1080/00138382108596411

曲 Published online: 13 Aug 2008.

Submit your article to this journal $₫$

ЏII Article views: 3

Q View related articles $₫$ 


\section{Vers Libre in Theory and Practice.}

I.

The impulse to write this article came to me from F. S. Flint's Preface to his Otherworld: Cadences, published in 1920 by The Poetry Bookshop $(5 /-$ net). This preface is a remarkable piece of work and well worth reading, weighing and considering, though it certainly does show the author's limitations and idiosyncrasies (a thing that it was bound to do) together with a lack of general information and literary equipment, which I venture to think was by no means so inevitable. Nevertheless, it shows itself on the very first page of the Preface. Because Mr. Flint uses the word cadence in a Pickwickian or Flintian sense, does it therefore follow that Chaucer, in the House of Fame, (Second Book, lines 112-115) does so likewise? And is it justifiable to base one's opinion of Old-English metre on a translation from Cynewulf, containing the phrase 'with a cadenced song' and a few not very effective alliterations? The Greek choruses, to whose scansion Mr. Flint refers, were certainly not what he would term cadences. On the other hand, I think any negro hearing such a chorus, say the well-known one with which Euripides closes quite a number of tragedies - o mega semnê Nikê \&c, a march! - would prick up his ears, blow out his cliest, and, unable to keep his haunches still, involuntarily join!

But why should Mr. Flint resort to such questionable arguments, when his position is sufficiently strong as it is? He has written rimed poems himself, and has himself composed verses whose metric scansion will do; he knows the tricks of the trade quite well. And so do many others nowadays, far too many. Our literary groves harbour hosts of songsters, who starling-like are content to repeat and repeat picked-up melodies ad infinitum. Every warbler 'has his tune by heart', now as in the dispassionate times of the couplet-stringing 'Augustans'. This fact is a proof to Mr. Flint that our traditional rime-schemes and metrical patterns are outworn. 'The history of English poetry in verse is the story of the exhaustion of the effects to be obtained from rhyme and metre, - of the exploitation of a mine in which the main lodes have at last given out. It may or may not be foolish to deplore that poetry should have been tied down so long to such a task, but it can hardly be denied that, except for a few poets who have discovered an odd vein that had not been worked, there is no writing nowadays in metre and rhyme that does not echo with all the feet and all the rhymes of the past, so much so that some poets break up their metres and smother their rhymes, until neither metre nor rlyyme has any other function than to ruin the style of their poems. Swinburne gave the coup de grâce (and the coup de Jarnac too) to English rhyme and metre.'

To which one might allege that in all likelihood the percentage of literary starlings nowadays is not so very much higher than it was in the past. Our ears, deafened by multitudinous songs that yield us no delight, would have us believe it was otherwise in the days of good king Cole, but in this our ears are wrong. I suppose that rimes like fire and desire will grate upon Mr. Flint's ear, much as Dutch hart and smart grate upon mine, but that such things annoy is no present-day discovery, nor did it take centuries to find it out. Artistic tricks or stunts antiquate with incredible swiftness. Who 
among living rimesters would now think of using the dodge that poor Oliver Goldsmith affected: busy train - pain; trade's unfeeling train - swain; harmless train - pensive plain etc. etc.? And yet, are they likely to produce a single poem that will stand the test of time as The Deserted Village has done? And is not the tyranny of the dead, against which Mr. Flint declaims, more especially a tyranny of the recently dead or even - of the living? Surely it is living authors who create fashions, often, it is true, after plenty of toil and moil to obtain recognition for their methods, and such fashions have a knack of lingering on, - even in Mr. Flint's work. A reviewer, in the Times Literary Supplement, has pointed out certain lines in Otherworld whose only begetter was Walt Whitman. I think that strong and sincere personalities will always contrive to express themselves in a sincere and markedly personal way, no matter what forms they choose, adopt or invent. But there is another side to the question.

\section{II.}

In the beginning, as soon as gregarious man was man, there was poetry; and this poetry was undivorceably wedded to rhythm; and this poetry was thythm. It used words, but more often than not these words were mixed with plenty of meaningless shouts, grunts, or wails. It used tones, but only incidentally and without much striving for the harmony that we now call musical, the first rude accompaniment being invariably that of instruments of percussion. It was art, because its exhilarating, exalting or soothing effects were produced and undergone intentionally. And it was community-art, not only because it made its appeal either to the whole tribe or to an organic unit of it: to a body of men engaged in dragging away a tree, or in driving piles into muddy soil; to a company of girls tilling the fields or pounding corn into meal; to a hunting-party marching out to kill a bear or to set pitfalls for some blundering hippopotamus; but chiefly because it claimed the participation of each individual in its performance. It was dancing and singing; it was work and play; it was dumb show, magic and ritual; it was the inspiriting, the alacrifying helper of the toiling body, and the divinely intoxicating liberator of the wingflapping spirit. It was all these things, and yet it was one.

It was community-art, but the community as such could no more create art then than it can now. Its work consisted in accepting (and acceptance implies the possibility of rejection) whatever some artistically gifted individual would offer it; in remembering the words of such a creation; and most especially in preserving its rhythmical pattern. This pattern would remain the same, year after year, century after century, whereas the words, never very clear perhaps, would soon become unintelligible and be gradually supplanted by others. Every occurrence that concerned the tribe would not simply be an excuse for a choric dance and song, but would positively demand one, and then some tribal praecentor or rather choregos would show his gift of improvisation, his fellow tribesmen and (or) tribeswomen supplying an enthusiastic - i.e. an Orphic or Dionysiac - chorus, which left the chorêgos time to collect his thoughts and invent some new lines. The lineal descendants of these tribal poets are: the chantyman on board a vessel, the foreman of a body of rammers, and the man who, at a wedding-feast in North-Brabant, treats his delighted audience to the ever-varying horrors of the Raamsdonk murder. ${ }^{1}$ )

I) See Appendix. 
Rhythmical patterns were rigid from the first and continued to be so. They necessitated inversions, mutilations of words, syllables elided and lopped off as well as syllables added. ${ }^{1}$ ) All the things that make Homer difficult, his many synonyms, his bewildering use of verbal forms, are characteristic of the poetry of primitive communities.

Rime was a natural development. It must have originated in the repetition of words by the chorus. But among the lines improvised by the leader there must have been, from the very beginning, lines that rimed as well as lines that did not rime. The chime of the riming lines would of course appeal to the listeners, and at the same time its mnemonic value would be a powerful help to rhythm in preserving old 'songs' celebrating the prowess of a hero or the deeds of a god or lightening the labour of treading out wine and of grinding corn in querns. At the same time its regular use, aided no doubt by the invention of stringed instrumenls and flutes, must often have tended to make rhythmical patterns less rigid, and inversely the observation of this tendency may occasionally have led to rime being tabooed by masters in the craft. But in both cases, as civilisation progressed and performances became less noisy, greater attention would be paid to the words and greater demands would be made upon the poet as a word-artist. The worship of the cultured would be transferred from Dionysus to Apollo. ") But Dionysus persistently refused to be completely discarded.

\section{III.}

It is doubtful whether any literary art is possible which is purely Dionysiac; it is equally doubtful whether any poetry can be exclusively. Apollo's. The essence of art is compromise. An artist not only strives to express himself, but he strives at the same time to impress the minds of others, and the whole difference between community-art and individualistic art resolves itself into a matter of more or less. Purely individual experiences and feelings are incommunicable, and cannot, therefore, furnish the raw material for a poem. On the other hand, that which is common to everyone will not be worth talking or singing or writing about, and can never be sufficient incentive for a poet to make himself heard. The wordartist may invent some new terms and may pervert some old ones, but the bulk of his vocabulary he holds in common with millions of others. Now these others are accustomed to certain forms of art which time has gradually evolved. Entirely unfamiliar forms will repel, but too familiar forms will fail to appeal. And next, every artist must try to draw his hearer or hearers away from every-day life and its humdrum concerns. In doing this he cannot avoid making use of rhythm for its enthusing effects, but the stronger the rhythm, the greater its intoxicating power and the wider its appeal, whereas Flintian cadences are simply intended to be just strong enough to lure their reader away from reality.

1) The later makeshift of music which neither Purcell nor Handel disdained, viz. prolonging one vowel in singing a succession of tones, was unknown and syllables were repeated instead.

3) It need not be objected here that in Greece Apollo was the elder god: in the nature of things Greek Dionysus-worship must have been a reversion, and so must that of Cybele. For the effect of instruments of percussion compare Lucretius : tympana tenta tonant palmis et cymbala circum ..... (De Rer. Nat. II 6I8.) 
Fat black bucks in a wine-barrel room,

Barrel-house kings, with feet unstable,

Sagged and reeled and pounded on the table,

Pounded on the table,

Beat an empty barrel with the handle of a broom,

Hard as they were able,

Boom, boom, Boom,

With a silk umbrella and the handle of a broom,

Boomlay, boomlay, boomlay, Boom.

Then I had religion, Then I had a vision,

I could not turn from their revel in derision.

Then I saw the Congo, creeping through the black,

Cutting through the forest with a golden track.

Then along that river bank

A thousand miles

Tattooed cannibals danced in files;

Then I heard the boom of the blood-lust song

And a thigh-bone beating on a tin-pan gong...

This is by the American Nicholas Vachel Lindsay, than whom there is no more Dionysiac poet living. I think his Congo a very good thing. It is art, but it is noisy and - it cannot do without the noise. What is the harm? With unsophisticated listeners it produces the effect it was meant to produce. That makes it community-art. And is there anyone who can detect any note of insincerity in it?

\section{Eau-Forte.}

On black bare trees a stale cream moon Hangs dead, and sours the unborn buds.

Two gaunt old hacks, knees bent, heads low, Tug, tired and spent, an old horse tram.

Damp smoke, rank mist fill the dark square;

And round the bend six bullocks come.

A hobbling, dirt-grimed drover guides

Their clattering feet their clattering feet 1

to the slaughterhouse.

This is by F. S. Flint, and it has merits of its own. But besides that it is not community-art (and was not meant to be) it is not sincerer than Lindsay's tom-tom minstrelsy. And it is not wholly Apollonian! For one thing the rhythm is quite regular, with one intentional exception towards the end, and for another there is the repetition of this very exception : their clattering feet. ${ }^{1}$ )

Similar observations might be made concerning

\section{Devonshire.}

The little Heddon roars over its stones towards its mouth

Between two cliffs mounting up, one with the grey-brown haze

Of the budding oak-woods and the line of the path athwart them,

As though cut with a knife;

And the other grey with loose shale, and here and there

The gorse in bloom over the dead, brown bracken,

That springs again, green once more, from its death.

The little Heddon roars over its stones between

Its violets, primroses and celandines to the sea.

1) The word sours in the second line 1 think rather far-fetched. 
And, friends, what am I doing here beside you and the Heddon?

Why did I come to you with my heart-ache and my cares,

Falsely to brighten your life with the foil of my darkness?

Why did I come to your pine-woods?

The little Heddon roars over its stones to the sea.

My life grated on in its groove, and that groove

Brought me to you, but see! the little Heddon roared over my brain,

And for a day washed the mist from it, cleared the clog of it,

And the groove is no longer there.

Yet I shall leave you; I shall take back my groovc,

With a keener edge to my heart-ache and a different tune:

The little Heddon roaring over my brain to the sca!

1 like this poem very much, but maintain again that its effect is to a considerable extent Dionysiac. Again it is the varied repetition of one memorable line that accounts for about half the beauty of the poem. And what a simple device after all! And so easy to imitate.... And the mischief is that without some such device it is impossible to give shape to a poetical thought. This method of F. S. Flint cannot be named the discovery of an odd vein that had not been worked: it is a mine that has been worked from the first and is in no danger of ever giving out before 'God burn up Nature with a kiss.'

And where in F. S. Flint's work, as e.g. in the title-poem of Otherworld, these simple devices are altogether absent, ${ }^{1}$ ) the result is not satisfactory. There are many pretty lincs, but no expectations being raised and none fulfilled (or partly fulfilled, just enough to give a zest to a partial disappointment) our imaginations are not set free. Line after line we must discover a new cadence; the rush is not great and full and strong enough to sweep us along with it; Dionysus, slighted by the poet, has been revenged. When, after finishing the poem, we set ourselves to recollect what we have read, there are no memorabie lines haunting us, we have not been given any tune 'for the blood to jig to'. We shall remember a certain number of pictures, but the pictures will be unable to call up the words that produced them. The cadences were too free and too loosely strung.

'Clarity and sincerity of speech and purpose are the perennial qualities of all good poetry, and those who will strive after these qualities (since none of us is absolutely clear and sincere, they can only be obtained by

l) Here follows a typical bit:

And now in the afternoon,

When the children are at their school,

Three meadows away,

Hidden by hedges and a row of Lombardy poplars,

And their mother is teaching them and their playmates,

I sit dreaming on the verandah in the shade.

The warm sun falls on the crowfeet and buttercups

In the field before me;

The golden flowers nod and wave and kiss

As a light, warm wind passes over them.

The leaves are singing;

And faintly behind their monotone,

1 hear the singing of children.

Mournfully, a cuckoo calls "Cuck-oo!"

A blackbird scuttles from a spinney;

And I sit in a dream

And drink my coffec

And smoke my cigarette. 
hard work), and who will disburden themselves of the lumber bequeathed to them from the past, are the men who will be heard, and who will lift the word poetry out of the contempt in which it is held by the many who do not understand, or despise, or smile tolerantly at the meaningless rituals of verse.' This is what Flint says, but I wonder. I wonder whether the poet will be more of a poet by being a Hamlet, sicklied o'er with the pale cast of thought, as regards the sincerity of his feelings and the scientifically exact rendering of them. I wonder whether he will make his art more acceptable by stating - instead of 'I can't forget you, Clara!' - : 'I have not yet been able to forget you ; it may take me three years, or even four.' It is one thing to be entirely sincere and another to convey the impression of absolute sincerity. But excessive sophistication is an enemy to both, and therefore an enemy to art.

WILlem VAN DOORN.

\title{
Appendix.
}

Compare the following passage from Ernest Poole's novel The Harbour (Macmillan ; p. 45.)

"There she lay, the long white ship, laden deep, settled low in the water. I could see the lines of little dark men heaving together at the ropes. Each time they hove they sang the refrain, which, no doubt, was centuries old, a song of the winds, the big bullies of the ocean, calling to each other as in some wild storm at sea they buffeted the tiny men who clung to the masts and spars of ships:

\author{
"Blow the man down, bullies, \\ Blow him right down! \\ Hey ! Hey! Blow the man down! \\ Give us the time to blow the man down!"
}

But what were the verses? I could hear the plaintive tenor voice of the chantyman who sang them - now low and almost mournful, now passionate, thrilling up into the night, as though yearning for all that was hid in the heavens. Could a man like that feel things like that? But what were the words he was singing, this yarn he was spinning in his song ?

I came around by the foot of the ship and walked rapidly up the dockshed toward one of its wide hatchways. The singing had stopped, but as l drew close a rough voice broke the silence :

"Sing it again, Paddy !"

1 looked out. Close by on the deck, in the hard blue glare of an arclight, were some twenty men, dirty, greasy, ragged, sweating, all gripping the ropes and waiting for Paddy, who rolled his quid in his mouth, spat twice, and then began:

"As I went awalking down Paradise Street

A pretty young maiden I chanced for to meet."

A heave on the ropes and a deafening roar:

"Blow the man down, bullies,

Blow him right down!

Hey $\mid$ Hey ! Blow the man down !" 


\section{Some Books to be Consulted.}

Francis Gummere,

Karl Bücher,

Frank Sidgwick,

T. F. Henderson,
The Beginnings of Poetry.

Arbeit und Rhythmus.

The Ballad.

The Ballad in Literature.

\section{Affective Sound-Changes.}

It has sometimes been suggested that exceptions to laws of sound-change may be due to the emotional value of a word, which affects its pronunciation. Phoneticians do not seem to have taken to the idea. In the third edition of my English Sounds $(\S 262)$ I have proposed affective lengthening as the explanation of the statements made by English phoneticians, that glad, mad, sad, bad have a longer vowel than cad, lad, etc.

In Wells, Joan and Peter, ch. $2, \S 1$, p. 20, I found the following example.

Mrs. Bagshot-Fawcett gets positively lush about him. It was George she always lurved, Mrs. Bagshot-Fawcett says, but she (i. e. the Princess) accepted his brother for Reasons of State.

In this case lurve seems to be an example of affective (and at the same time affected) lengthening.

A case of affective rounding is supplied by Dutch [ncj] for [ne] nee. The rounding and pointing of the lips, characteristic of indifference, causes the change.

It seems to me, however, that the theory of affective sound-changes may explain more than such occasional deviations from regular development. In order to explain this I must firs/ discuss the question of breath and voice.

In old-fashioned grammars, if they treated of sounds at all, such consonants as $p, t, k, f$, etc. were often called hard, in contrast to $b, d, g, v$, which were called soft. A definition of the difference was not given, for the distinction was based on a rather vague acoustic impression, as was usual before the advent of modern phonetics. The distinction of hard and soft came to be pushed into the background; indeed, the success of the English school of phoneticians seemed to have finally disposed of it as unscientific. There is not a word on it in Sweet's books on phonetics. Continental phoneticians, however, were bound to consider the difference, for they found that hard and soft in the languages they studied was by no means invariably equivalent to breathed and voiced. Rousselot, to begin by quoting a Frenchman, in his Précis de la Prononciation franfaise (1903) p. 50 explains: "Une consonne est douce ou forte en raison de l'intensité relative de l'effort articulatoire nécessaire pour la produire..... Comparez encore, en plaçant le doigt entre les lèvres, $v$ et $f, b$ et $p: v$ et $b$ sont des douces; $f$ et $p$, des fortes. Comme, dans la sonore ${ }^{1}$ ) l'effort se partage entre le larynx et l'organe articulateur (lèvres ou langue) la sonore est toujours une douce. Mais la douce n'est pas toujours une sonore. De même, la forte est naturellement sourde, l'effort articulatoire s'opposant à l'action du larynx."

The distinction is of practical use, as is shown on p. 85: "La forte qui devient sonore se transforme par le fait même en douce. Mais la douce

j) i. e. voiced consonant. 